\title{
Quantitative glomerular morphology of the normal and diabetic baboon kidney
}

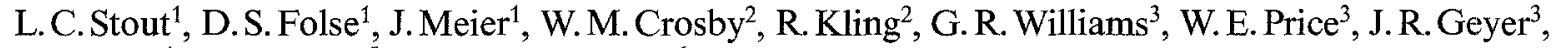 \\ R. Padula ${ }^{4}$, E. Whorton ${ }^{5}$ and P. Kimmelstiel ${ }^{6 *}$ \\ Departments of ${ }^{1}$ Pathology, ${ }^{4}$ Surgery and ${ }^{5}$ Preventive Medicine and Community Health at The University of Texas Medical Branch, \\ Galveston, Texas, and \\ Departments of ${ }^{2}$ Gynecology and Obstetrics, ${ }^{3}$ Surgery and ${ }^{6}$ Pathology at The University of Oklahoma Health Sciences Center, \\ Oklahoma City, Oklahoma, USA
}

\begin{abstract}
Summary. This is a study of quantitative glomerular morphology in 14 normal and 6 long-term diabetic female baboons between 3 and 25 years of age. In the normal female baboon, peripheral glomerular capillary basement membrane thickness increased until around 10 years of age, reached a plateau between 10 and 20 years of age, and possibly decreased at 25 years of age. Mean values for young ( 3 to 7 years of age) and older (10 to 25 years of age) controls were $266 \mathrm{~nm}$ and $329 \mathrm{~nm}$ respectively. Fractional volumes of mesangial matrix $(8.9 \%)$ and mesangial cells $(6.8 \%)$ were not affected by age. Glomerular basement membrane thickness and the volume of mesangial matrix increased progressively in female baboons with poorly controlled pancreatectomy-induced diabetes, while the volume of mesangial cells remained unchanged. After 106 to 145 months of diabetes, glomerular basement membrane thickness and the volume of mesangial matrix were $558 \mathrm{~nm}$ and $18.7 \%$ respectively. These values were signifi-
\end{abstract}

cantly greater than those of the age-matched controls $(p=<$ 0.05 ). By light and electron microscopy, the normal baboon glomerular morphology, morphometric measurements and changes with age were similar to those in man. The renal changes in diabetic baboons were also similar in morphology and rate of development to those of mild to moderate diffuse diabetic glomerulosclerosis in humans, indicating that the baboon is an ideal model for the long-term study of diabetic glomerulosclerosis. The presence of considerable interanimal variability in the degree of glomerulosclerosis attained after prolonged diabetes suggested that glomerulosclerosis progressed at different rates in these models. The reason for this was not apparent.

Key words: Basement membrane, mesangium, diabetes, baboons, pancreatectomy, quantitative glomerular morphometry.
The recent development of relatively simple and reproducible techniques for quantitatively measuring glomerular components [1-4] has facilitated not only the study of diabetic renal disease, but also the comparison of findings among the different species used in such studies. These comparisons are important because certain glomerular components are affected by age and sex in some species but not in others, and certain glomerular components are differently affected by diabetes in different species.

The changes of advanced diabetic glomerulosclerosis in humans have been well known for years, and the early changes (up to 5 years) have been well documented by the quantitative morphometric studies of Osterby $[5,6]$. However, there is a dearth of information concerning the morphologic events that occur between these two stages [7, 8]. Because of this lack of morphologic data, and the fact that a substantial percentage of

\footnotetext{
* Deceased
}

human Type 1 (insulin-dependent) diabetic patients do not develop clinical diabetic nephropathy [9], significant questions remain unanswered. It is possible that clinical diabetic nephropathy is due to a more rapid progression in some patients of the mild to moderate glomerulosclerosis that occurs during the first few years of diabetes $[5,6,10]$. On the other hand, it could be due to some other process, such as hypertension $[11,12]$ or immune complex disease [13, 14] being superimposed upon mild to moderate diabetic glomerulosclerosis. At present, two groups $[7,8]$ are studying this question using quantitative glomerular morphometry in man. A serious impediment to such studies is the difficulty in justifying renal biopsies on patients without evidence of renal impairment. Because of this, an animal model is needed that develops diabetic glomerulosclerosis similar in morphology to that of man.

The main problems with animal models of diabetic glomerulosclerosis have been that, although small animals develop glomerular lesions rapidly, the lesions dif- 
fer somewhat from those in humans, and lesions in large non-human primates develop so slowly that the expense and difficulty involved in keeping diabetic animals alive for prolonged periods are prohibitive. Only one other long term quantitative morphologic study has been reported using non-human primates [15], and this concerned animals with several types of diabetes.

In this paper, we describe the effects of long term (106 to 145 months) poorly controlled pancreatectomyinduced diabetes on peripheral glomerular capillary basement membrane (GBM) thickness, fractional volume of mesangial matrix (VMM) and fractional volume of mesangial cells (VMC) in baboons. In addition, we report normative data for GBM thickness, VMM and VMC in female baboons between 34 months and 25 years of age. The quantitative mesangial measurements have not been previously reported in diabetic or normal non-human primates.

\section{Materials and methods}

\begin{abstract}
Animals
Twenty female baboons (Papio anubis and Papio cynocephalus) were used in this study. Seven were born and reared in the primate facility and 13 were obtained commercially. Ages of the latter were estimated using body weight, dental condition and oestrous cycle characteristics. Actual and estimated ages at the time of the first and last renal biopsies ranged from 34 months to 25 years. Diabetes was induced by surgical total pancreatectomy. There were 6 long term diabetic and 14 control baboons. Diabetes was treated with single daily injections of 12 to $22 \mathrm{U}$ of isophane insulin. Insulin dosage was adjusted to maintain all animals in poor diabetic control (average daily urine glucose concentration greater than $2000 \mathrm{mg} / \mathrm{dl}$ ). Diabetic control was monitored by daily urine tests for glucose with Clinitest tablets and for ketone bodies with Acetest tablets. Fasting blood glucose levels were obtained annually, and haemoglobin $\mathrm{A}_{1_{c}}\left(\mathrm{HbA}_{1_{c}}\right)$ levels were measured by cation exchange chromatography every three months during the last 2.5 years of the study. Renal function was assessed by approximately annual blood urea nitrogen determinations and urinalyses. Proteinuria greater than $100 \mathrm{mg} / \mathrm{dl}$ by Bili-Labstix was further investigated by 24 -h urine protein determinations, with the upper limit of normal being arbitrarily set at $100 \mathrm{mg}$ per $24 \mathrm{~h}$. One diabetic animal (N) died with hypoglycaemic shock and the remainder were killed.

The animals were arbitrarily divided into four groups based upon age and diabetic status. Group I (young controls) consisted of diabetic animals at baseline and controls, all of whom were 7 years of age or younger. Group II (older controls) consisted of control animals between 10 and 25 years of age. Group III consisted of diabetic animals midway through the study (after 55 to 81 months of diabetes), and Group IV consisted of diabetic animals at the end of the study (after 106 to 145 months of diabetes).
\end{abstract}

\section{Renal biopsies}

Open (transperitoneal or retroperitoneal) needle biopsies were done at baseline, at killing (after 106 to 145 months of diabetes), and approximately midway between (after 55 to 81 months of diabetes) in the diabetic animals. In one diabetic animal (P) the midway biopsy was unsatisfactory, and in another (C) a fourth biopsy was done. Seven controls had two biopsies, 28 to 44 months apart, and the remainder had single biopsies. Glomeruli for electronmicroscopy were selected midway between the medulla and the renal capsule when possible. Tissue for electronmicroscopy was diced, fixed in paraformaldehyde, post-fixed in osmium tetroxide and embedded in Epon 812. Blocks were thick sectioned until a glomerulus was found that had an intact Bowman's capsule and was located at least one tubular diameter from the edge of the tissue. The block was then thin sectioned at 50 to $70 \mathrm{~nm}$ with an LKB Ultratome III, LKB Instruments, Gaithersberg, Md, USA. The thin sections were placed on $1 \mathrm{~mm}$ by $2 \mathrm{~mm}$ Formvar coated slot grids and stained with uranyl acetate and lead citrate. Random photographs of the entire glomerulus were obtained with a Phillips 300 Electron Microscope, Philips Electronic Instruments, Inc, Mahwah, NJ, USA, by using a preset system of turning the controls after locating the bottom left corner of the glomerulus. A calibration grid $(28,800$ lines per inch, EF Fullam, Inc, Schenectady, NY, USA) was photographed along with each glomerulus and used to determine the final magnification of each set of prints. Care was taken to ensure that the focus adjustment of the electron microscope and the enlarger remained unchanged for each set of pictures. The magnifications of the micrographs used ranged from 14,400 to 15,192 .

Usually three glomeruli were examined quantitatively from each biopsy. In one biopsy, only two glomeruli were available, and in four biopsies, only one. All of these were in the diabetic animals. In $\mathbf{P}$ and $\mathrm{C}$, the baseline biopsies, and in $\mathrm{A}$ and $\mathrm{N}$, the mid way biopsies, contained one glomerulus each, while in $\mathrm{N}$, the baseline biopsy contained two glomeruli. The reason for this is that the baseline and midway biopsies were originally measured using a modification of the much more time consuming method first developed by Osterby [16]: Therefore, when the study was repeated using the newer methodology [1-4], there was a shortage of glomeruli in four of the diabetic baboons. However, a comparison of the results between the two methods showed that the GBM thickness was within $8.3 \%$ in the baseline biopsies and $17.1 \%$ in the midway biopsies. The greater variation among glomeruli with thicker GBM is consistent with our experience and that of others [15]. Because of the concordance between the results of the two methods, and the fact that two glomeruli per biopsy have been said to be sufficient [15], it was felt that the data from the newer methodology was representative despite the decreased number of glomeruli in the four animals.

\section{Measurements}

GBM thickness was measured using the orthogonal intercept method of Gunderson, Jensen and Osterby [1] and Jensen, Gunderson and Osterby [2]. A 16-point grid was placed over each micrograph, and the distance between endothelial and epithelial cell membranes was classified at each intersection between a grid line and the GBM-endothelial interface. The harmonic mean was calculated and then multiplied by $8 / 3 \pi$ to obtain the actual GBM thickness $[1,2]$. A mean of $59(6$ to 98 ) micrographs was used and a mean of 287 (28 to 596) orthogonal intercepts was classified for each biopsy.

VMM and VMC were determined by a point counting technique using an 80-point grid [3]. In sections where the transition between peripheral capillary area and mesangium was difficult to discern, the method of Steffes et al. [4] was used to resolve the issue. A mean of 4424 (396-7265) points was counted for each biopsy.

\section{Other renal studies}

Tissue from each biopsy was studied by light microscopy, and one glomerulus (in addition to those used for quantitative studies) from each biopsy was studied by electron microscopy. These sections were examined for the presence of sclerosed glomeruli, synechiae, crescents, mesangial nodules, fibrin cap lesions, capsular drop lesions, hyalinized arterioles, dense deposits, and tubular, interstitial and arterial lesions. 


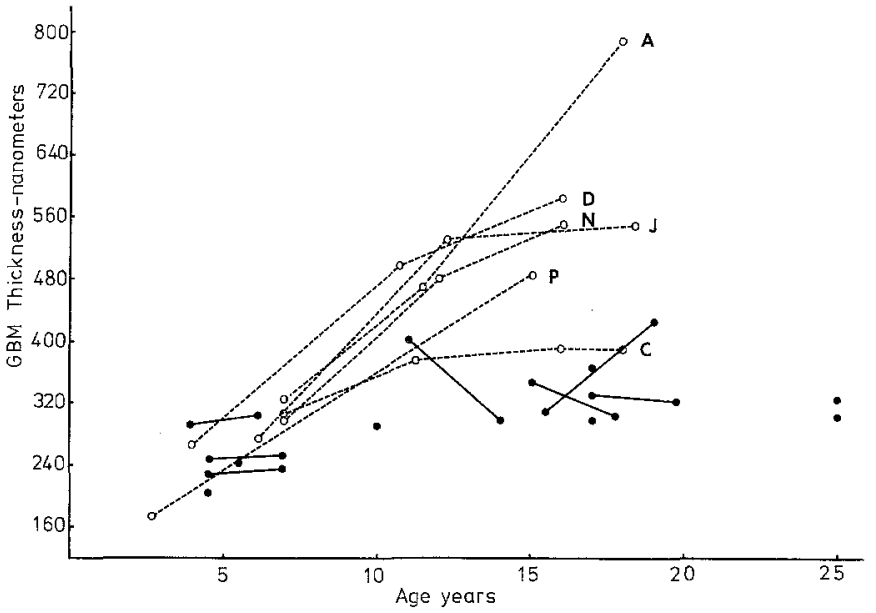

Fig. 1. Glomerular basement membrane thickness is plotted against age in control ( - ) and diabetic $\left(\mathrm{O}_{-}-\mathrm{O}^{-}\right)$female baboons. Individual diabetic baboons are identified by capital letters

Table 1. Models used to represent the relation of glomerular basement membrane (GBM) thickness with age

\begin{tabular}{|c|c|c|c|}
\hline \multirow[t]{2}{*}{$\begin{array}{l}\text { Linear } \\
\text { model } \\
(n=20)\end{array}$} & $\begin{array}{l}\text { GBM width }=240+0.40 \\
(\mathrm{~nm})\end{array}$ & $\times$ age & \multirow[t]{2}{*}{$\mathrm{r}^{2}=0.42$} \\
\hline & t-values & & \\
\hline \multirow{2}{*}{$\begin{array}{l}\text { Parabolic } \\
\text { model } \\
(n=20)\end{array}$} & $\begin{array}{l}\text { GBM width }=160+1.8 \\
(\mathrm{~nm})\end{array}$ & $\times$ age $-0.0044 \times$ age $^{2}$ & $r^{2}=0.68$ \\
\hline & t-values & 3.87 & \\
\hline
\end{tabular}

a The t-values are listed below their respective regression coefficients

Table 2. Glomerular basement membrane (GBM) thickness and fractional volume of mesangial matrix and mesangial cells in control and diabetic baboons $^{\mathrm{a}}$

\begin{tabular}{llcll}
\hline Group & $n$ & $\begin{array}{l}\text { GBM thick- } \\
\text { ness (nm) }\end{array}$ & $\begin{array}{l}\text { Volume } \\
\text { mesangial } \\
\text { matrix (\%) }\end{array}$ & $\begin{array}{l}\text { Volume } \\
\text { mesangial } \\
\text { cells (\%) }\end{array}$ \\
\hline $\begin{array}{l}\text { 1. Young controls } \\
\text { (Control and dia- }\end{array}$ & & $266 \pm 41.4$ & $8.8 \pm 1.6$ & $7.5 \pm 3.3$ \\
betic baboons at \\
baseline 3 to \\
$\begin{array}{l}7 \text { years of age) } \\
\begin{array}{l}\text { 2. Older controls } \\
\text { (Control baboons }\end{array}\end{array}$ & & $329 \pm 28.5$ & $9.1 \pm 2.4$ & \\
$\begin{array}{l}10 \text { to 25 years of } \\
\text { age) }\end{array}$ & & & & \\
$\begin{array}{l}\text { 3. Diabetic ba- } \\
\text { boons after 55 to } \\
81 \text { months of dia- }\end{array}$ & 5 & $475 \pm 51.4^{\mathrm{b}}$ & $14.4 \pm 1.8^{\mathrm{b}}$ & $7.3 \pm 2.7$ \\
betes & & & \\
$\begin{array}{l}4 . \text { Diabetic ba- } \\
\text { boons after 106 to } \\
\text { 145 months of } \\
\text { diabetes }\end{array}$ & 6 & $558 \pm 132.7^{\mathrm{b}}$ & $18.7 \pm 4.2^{\mathrm{b}, \mathrm{c}}$ & $8.8 \pm 2.2$ \\
\hline
\end{tabular}

${ }^{\mathrm{a}}$ Values are means, SD. ${ }^{\mathrm{b}}$ Significantly different, $(p=<0.05)$ from groups 1 and 2 . ' Significantly different, $(p=<0.05)$ from group 3

\section{Statistical analysis}

Analyses were conducted separately for each variable using analysis of variance (AOV) procedures to assess the statistical significance of differences among group means. When the AOV results indicated significance $(p=0.05)$, further testing based on the use of ranges [17] was done to ascertain which of the group means were significantly different $(p=0.05)$ and which were similar.

To investigate the age-related changes in GBM thickness for normal female baboons, we first fitted these data to a single variable linear regression model using only age as the predictor of GBM thickness. We then fitted these data to a two variable linear regression model using age and age-squared as the two predictors of GBM thickness. F-tests were conducted to assess the overall significance $(p=0.05)$ of each model. If an overall model was found to be significant, each component of the model was then tested for significance $(p=0.05)$ using a Student's t-test.

\section{Results}

\section{Metabolic derangements}

Diabetes was relatively stable in all animals. Ketonuria occurred once or twice a year and responded within a day or so to temporary increases in insulin dosage. The cause for ketonuria was usually not obvious and was not associated with detectable clinical changes. All animals had bulky stools and mild steatorrhea (2.17-5.45 g stool fat $/ 24 \mathrm{~h}$ for diabetic baboons and $0.65-1.3 \mathrm{~g}$ stool fat $/ 24 \mathrm{~h}$ for control baboons) but steadfastly refused various pancreatic enzyme preparations, regardless of how cleverly they were disguised. All animals were lethargic but appeared reasonably healthy despite the prolonged apancreatic and poorly controlled diabetic state. Both control and diabetic baboons weighed between 11 and $19 \mathrm{~kg}$. The weight of control baboons was stable throughout the study. Diabetic baboons A, J, C and D maintained their weight throughout the study. Diabetic baboon $\mathrm{P}$ gained $4 \mathrm{~kg}$ and diabetic baboon $\mathrm{N}$ lost $3 \mathrm{~kg}$. Serum lipid profiles in diabetic and control baboons have been reported elsewhere [18].

\section{GBM thickness}

In the normal female baboon, GBM thickness increased between 3 and 10 years of age, remained constant between 10 and 20 years of age, and possibly decreased at 25 years of age, although there were only 2 animals over 20 years of age (Fig.1). When we fitted these data to the single variable and the two variable models, F-tests showed both to be significant $(\mathrm{F}=19.55 ; \mathrm{df}=2,17$ for the two variable model, $p<0.05$ and $\mathrm{F}=13.91 ; \mathrm{df}=1,18$ for the single variable model $p<0.05$ ). Furthermore, t-tests (Table 1) showed that the age component was significant in both models $(p<$ 0.05 ), that the age-squared (quadratic) component was also significant in the two variable model $(p<0.05)$ and that the two variable model represented the data better. This supported the impression that GBM thickness increased with age until maturity, after which there was 

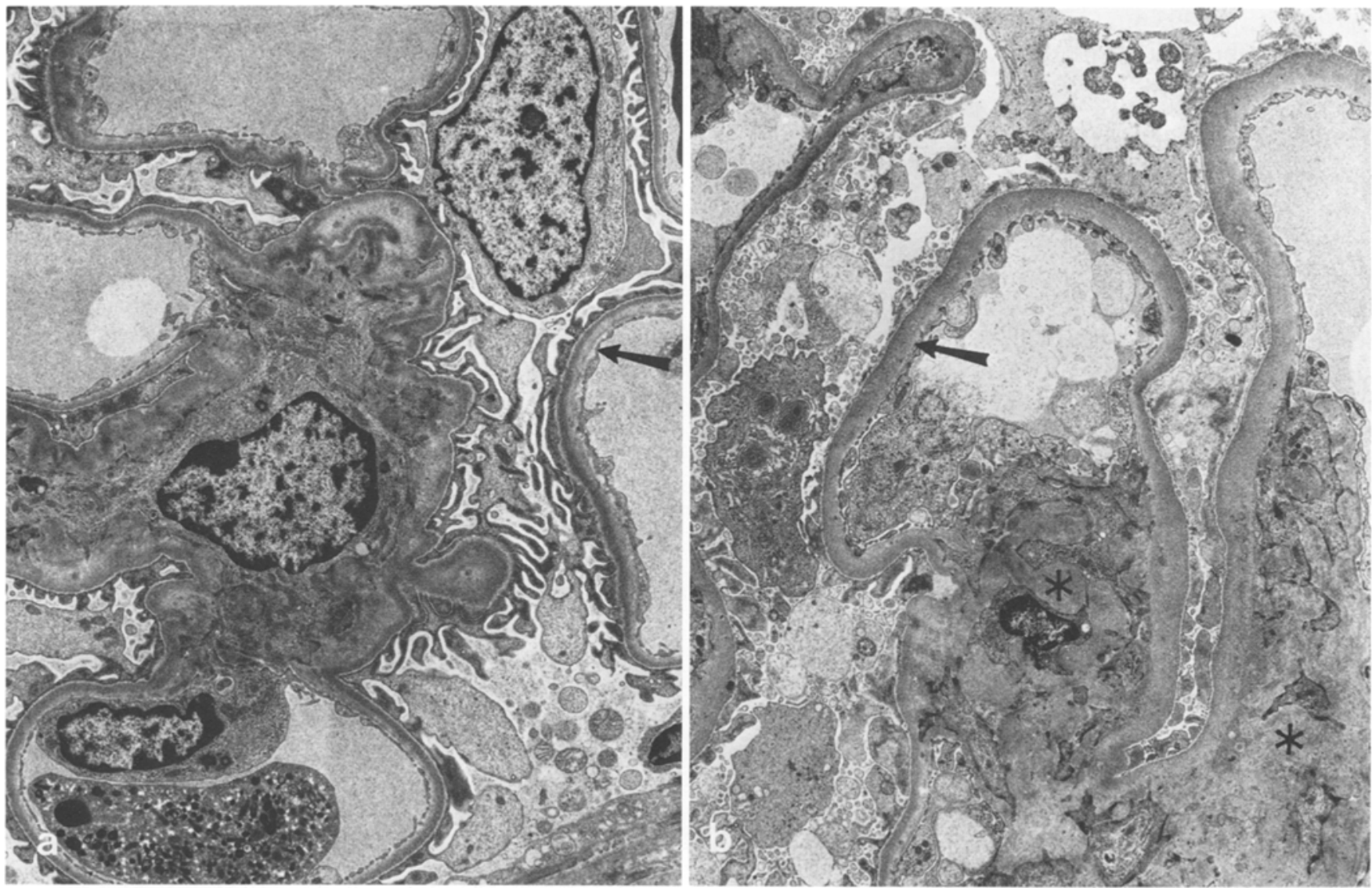

Fig. 2 a and b. Electronmicrographs of glomeruli from control baboon "B", 25 years of age (a), and diabetic baboon "P", 15 years of age, after 145 months of diabetes (b). The thicker peripheral glomerular basement membranes (arrows), and the expansion of the mesangial matrix (asterisks) in the diabetic baboon are obvious. Uranyl acetate and lead citrate $\times 9,193$ in a, and $\times 8,876$ in $\mathbf{b}$

Table 3. Fractional volume of mesangial matrix and mesangial cells in diabetic baboons at baseline and after various durations of diabetes

\begin{tabular}{llcc}
\hline Animal & $\begin{array}{l}\text { Duration of } \\
\text { diabetes } \\
\text { (months) }\end{array}$ & $\begin{array}{l}\text { Volume } \\
\text { mesangial } \\
\text { matrix (\%) }\end{array}$ & $\begin{array}{l}\text { Volume } \\
\text { mesangial } \\
\text { cells }(\%)\end{array}$ \\
\hline A & Baseline & 12.2 & 10.9 \\
& 56 & 15.2 & 6.6 \\
C & 133 & 22.2 & 12.0 \\
& Baseline & 7.6 & 15.9 \\
& 55 & 16.8 & 10.2 \\
& 106 & 16.7 & 8.9 \\
$\mathrm{~N}$ & 128 & 14.8 & 6.4 \\
& Baseline & 8.5 & 6.9 \\
& 62 & 11.9 & 3.0 \\
$\mathrm{D}$ & 106 & 11.9 & 6.0 \\
& Baseline & 7.5 & 4.7 \\
& 81 & 13.4 & 7.6 \\
$\mathrm{P}$ & 143 & 20.3 & 10.4 \\
& Baseline & 8.7 & 6.4 \\
$\mathrm{~J}$ & 145 & 22.3 & 9.4 \\
& Baseline & 7.9 & 6.0 \\
& 71 & 14.8 & 9.1 \\
& 145 & 19.8 & 7.5 \\
\hline
\end{tabular}

no further increase until advanced age, when there was a suggestion of some decrease.

GBM thickness was significantly increased $(p<$ 0.05 ) in the diabetic animals after 55 to 81 months of diabetes $(475 \mathrm{~nm})$ and at killing after 106 to 145 months of diabetes $(558 \mathrm{~nm})$. The diabetic values at killing, although higher, were not significantly different from those after 55 to 81 months of diabetes (Table 2). Inspection of individual diabetic animals (Fig. 1) showed that the rate of increase in GBM thickness apparently decreased after the midway biopsy in three animals (D, N and $J$ ) and increased slightly in one animal (A). In the fifth animal $(\mathrm{P})$, the midway biopsy contained insufficient glomeruli for analysis. However, if the value obtained by the original methodology is used (GBM $=454 \mathrm{~nm}$ after 71 months of diabetes), then $P$ also exhibited a decrease in the rate of GBM thickening after the midway biopsy. In the sixth animal (C), with four biopsies, the rate of increase in GBM thickness throughout the course was less than that of all the other diabetic baboons. After 55 months of diabetes, her GBM thickness was $376 \mathrm{~nm}$ (1.66 standard deviations above the older control mean, $p=0.07$ ), and after 128 months of 
diabetes it was $393 \mathrm{~nm}$ ( 2.25 standard deviations above the older baboon control mean, $p=<0.05$ ).

\section{Mesangium}

Neither VMM nor VMC were affected by age in the normal female baboons. The VMM was significantly expanded in the diabetic animals after 55 to 81 months of diabetes $(p<0.05)$. Unlike the GMB thickness, this expansion progressed at a significant rate with the values after 106 to 145 months of diabetes being significantly greater $(p<0.05)$ than those after 55 to 81 months of diabetes (Table 2). In one animal (N), the VMM increase with diabetes was not significantly different from the age matched controls. The diabetic state had no effect on the VMC (Table 2). Values for VMM and VMC in the diabetic baboons should be considered tentative because of the reduced number of glomeruli available for study. The individual values for VMM and VMC in the diabetic baboons at each biopsy are shown in Table 3 .

One baboon with spontaneous diabetes for 3 + years was also studied. GBM thickness was significantly increased ( $410 \mathrm{~nm}, p=<0.05$ ), but VMM was not (9.1\%). Values from this animal were not included in the statistical analyses.

\section{Other renal studies}

None of the diabetic animals developed either important proteinuria or elevation of the blood urea nitrogen levels. Final checks for proteinuria were negative in diabetic animals $P, A, J$ and $N$ and less than $30 \mathrm{mg} / \mathrm{dl}$ in animal $\mathrm{C}$ and $\mathrm{D}$. Tests for proteinuria were negative or less than $30 \mathrm{mg} / \mathrm{dl}$ in all control baboons except for D75 and D-129, each of whom had single values of $100 \mathrm{mg} / \mathrm{dl}$. Subsequent $24 \mathrm{~h}$ quantitative urine protein determinations were $49 \mathrm{mg}$ and $82 \mathrm{mg}$ respectively. Proteinuria apparently does not develop with age in female baboons, since both 25-year-old animals had negative tests.

By light and electron microscopy, there was a diffuse increase in mesangial matrix and GBM thickness very similar to that of mild to moderate diffuse diabetic glomerulosclerosis in humans. These changes were not present in the control baboons (Fig. 2). Rare hyalinized arterioles were seen in diabetic animals $\mathrm{D}, \mathrm{A}$ and $\mathrm{P}$, and rare fibrin cap lesions were seen in animals $\mathrm{A}$ and $\mathrm{P}$. Despite 106 to 145 months (mean 133 months) of poorly controlled diabetes, none of the animals developed severe diffuse glomerulosclerosis and no mesangial (Kimmelstiel-Wilson) nodules were found. Changes suggestive of early nodules were occasionally seen in animals $A$ and $P$.

There was considerable interanimal variability in the degree of glomerulosclerosis manifest after 106 to 145 months of diabetes. Animals $\mathrm{C}$ and $\mathrm{N}$ both had minimal glomerulosclerosis, which was recognizable by electronmicroscopy, but not by light microscopy in $\mathrm{N}$. Animals $\mathrm{D}$ and $\mathrm{J}$ had mill glomerulosclerosis, and animals $\mathrm{A}$ and $\mathrm{P}$ had moderate glomerulosclerosis.

No relationship was found between glycaemic levels and glomerulosclerosis.

\section{Discussion}

This study shows that GBM thickness increased in the normal female baboon between 3 and 10 years of age, reached a plateau between 10 and 20 years of age, and possibly decreased at 25 years of age. The actual GBM width (dogs and rats have thinner GBM), its morphological appearance, and its changes with age are similar to those in humans [19], although more animals over 20 years of age need to be studied to be certain about the decline in GBM thickness with old age. The findings in baboons are also similar to those in normal rhesus monkeys [15], except that no decline in GBM thickness was found in the latter study. However, no data were reported on rhesus monkeys beyond 19 years of age. Baboons, rhesus monkeys and man differ from the rat $[20,21]$ and the dog [14], in whom GBM thickness progressively increases throughout life, although recently cited "unpublished results" indicate that GBM thickness in beagle dogs may reach a plateau at around four years of age [22]. We cannot comment on the observed difference in GBM thickness between human males and females [19], since the present study was limited to female baboons.

This study also shows that the VMM and VMC remained constant in normal female baboons between the ages of 3 and 25 years. These results are similar to those in humans [19]. Baboons and humans differ from the rat, in whom VMM increases with age [23]. VMM remains constant in normal beagle dogs up to 21 months of age [24], but quantitative mesangial studies beyond that age have not been reported.

GBM thickness increased progressively in the diabetic baboons, and was significantly different from that of the age-matched older controls. These findings are similar in morphology and rate of development to those in human Type 1 diabetic patients [5]. The findings are also similar to those in rhesus $[15,25]$ and Japanese monkeys [26], rats [20,21] and dogs [14, 24] made diabetic by a variety of methods. The VMM also increased in the diabetic baboons, similar to that observed in humans [6], dogs [24] and monkeys [25, 26] with diabetes, although the latter were not studied quantitatively. There is some controversy as to whether diabetic rats develop increased VMM; some say they do [27, 28], while others say they do not [23]. The VMC was not affected by diabetes in the baboons, which is similar to findings in humans during the first five years of diabetes [6]. The VMC was found to be increased in diabetic rats $[21,27,28]$ and in diabetic dogs in some studies [14] but not in others [24]. 
The above findings indicate that the baboon, because of its similarity to humans in both the normal and diabetic state, is a good model for the long-term study of renal changes in experimental diabetes.

The degree of GBM thickening varied considerably among the baboons after 106 to 145 months of diabetes. The reason for this is not clear. Although there probably was some difference in the degree of hyperglycaemia between the most and the least hyperglycaemic animal, the least hyperglycaemic animal was profoundly hyperglycaemic by any standards (mean $\mathrm{HbA}_{1 \mathrm{c}}$ for $\mathrm{C}$ was over three times the control value [29], and her mean fasting blood glucose level was $494 \mathrm{mg} / \mathrm{dl}$ ). This same variation was also present in the pancreatectomized rhesus monkeys of Jones et al. [15]. Three animals, each 13 years of age, had GBM thicknesses of approximately 275,360 , and $455 \mathrm{~nm}$ after 6,4 , and 5 years of diabetes respectively. All three animals were treated according to the same insulin regimen, so that their degree of hyperglycaemia was presumably similar (mean plasma glucose $322 \mathrm{mg} / \mathrm{dl}$ ). Two recent quantitative morphometric studies $[7,8]$ in long-term human diabetic patients have also shown marked variability in the degree of GBM thickening, although the degree of glucose control was not stated, and a recent study of beagle dogs [24] showed no effect of glucose control on GBM width after one year of diabetes.

The above data suggest that other factors beside the degree of hyperglycaemia may influence the severity of GBM thickening. The nature of these other factors remains to be determined. Possibilities would include immune complex disease, since Cavallo et al. [13] recently reported evidence of immune complex disease in renal biopsies from 18 of 41 diabetic patients, and Bloodworth and Engerman [14] noted dense deposits around the basement membrane in about $10 \%$ of their human diabetic patients. However, most of these patients had advanced diabetic glomerulosclerosis, and we found no dense deposits in the baboons reported here.

Another interesting feature was that four of the six diabetic baboons showed a decrease in the rate of increase in GBM width between the midway and the final biopsies. In three of the animals, this finding was associated with a progressive increase in the VMM during the same time intervals. This suggests that the control of synthesis and/or degradation of basement membrane proteins is governed by different mechanisms in the mesangium and the peripheral capillary wall. The lack of any concomitant change in the VMC is hard to explain, but seems to suggest that the mesangial matrix accumulation may not be due to increased cellular activity.

Considerable variability in GBM width was present between glomeruli after 106 to 145 months of diabetes in animals J, A and D. Similar variability was noted by Jones et al. [15] in 3 of 8 streptozotocin diabetic but none of 6 pancreatectomized diabetic rhesus monkeys. The reason for this variability is not obvious, and we cannot exclude the possibility that GBM thickening varies according to the location of the glomerulus in the renal cortex. Occasional electron micrographs in the diabetic baboons (see Fig.2) showed evidence that GBM thickening was focal, but in most cases, the involvement appeared to be diffuse.

Acknowledgements. This study was supported by a grant from The John A. Hartford Foundation, Inc. The authors are particularly grateful to Dr. M. Steffes and J. Basgen for demonstrating the morphometric techniques. Insulin was generously donated by E.R.Squibb \& Sons, Inc, and Clinitest and Acetest tablets were provided by the Ames Division of Miles Laboratories, Inc. Able assistance was provided by Drs. G. Psimenos, C. Tseng, B.Spargo, M.Arakawa, T. Bynum, J.Wulff, R.Shaver, J.Schmidt, D. Holmes, N.Granholm, V.Smith, J.Coalson, A. Levy, G. Beathard, K. Kawano and others. Expert technical assistance was provided by A.Welford, W.Clagg, C.Johnson, C. Haygood, Z. Proctor, A. Marchiando, C. Frey, T. Bednarek, H. Bradley, L. Stanich, A. Smith, K. Holdren, G. Todd, R. Hadden, P. Perez and others.

\section{References}

1. Gunderson HJG, Jensen TB, Osterby R (1978) Distribution of membrane thickness determined by lineal analysis. J Microsc 113: $27-43$

2. Jensen TB, Gunderson HJG, Osterby R (1979) Determination of membrane thickness distribution from orthogonal intercepts. $J$ Microse 115: 19-23

3. Elias H, Hennig A, Schwartz DE (1971) Stereology: applications of biomedical research. Physiol Rev 51: 158-200

4. Steffes MW, Leffert JD, Basgen JM, Brown DM, Mauer SM (1980) Epithelial cell foot process width in intact and uninephrectomized diabetic and nondiabetic rats. Lab Invest $43: 225-230$

5. Osterby R (1972) Morphometric studies of the peripheral glomerular basement membrane early in juvenile diabetes. I. Development of initial basement membrane thickening. Diabetologia 8 : $84-92$

6. Osterby R (1973) A quantitative electron microscopic study of mesangial regions in glomeruli from patients with short term juvenile diabetes mellitus. Lab Invest 29:99-110

7. Osterby R, Gunderson HJG, Horlyck A, Kroustrup JP, Nyberg G, Westburg G (1983) Diabetic glomerulopathy. Structural characteristics of the early and advanced stages. Diabetes 32 (Suppl 2): $79-82$

8. Mauer SM, Steffes MW, Ellis EN, Sutherland DER, Brown DM, Goetz FG (1984) Structural-functional relationship in diabetic nephropathy. J Clin Invest 74: 1143-1155

9. Deckert T, Poulsen JE, Larsen M (1978) Prognosis of diabetics with diabetes onset before the age of thirty-one. Diabetologia 14: 363-377

10. Mauer SM, Steffes MW, Connett J, Najarian JS, Sutherland DER, Barbosa J (1983) The development of lesions in the glomerular basement membrane and mesangium after transplantation of normal kidneys to diabetic patients. Diabetes 32: 948-952

11. Parving HH, Andersen AR, Smidt UM, Christiansen JS, Oxenball B, Svendsen PA (1983) Diabetic nephropathy and hypertension. The effect of antihypertensive treatment. Diabetes 32 (Suppl 2): 83-87

12. Mogensen CE (1980) Antihypertensive treatment inhibiting the progression of diabetic nephropathy. In: Ditzel J (ed) Diabetes and diabetes treatment III. Acta Endocrinol 94 (Suppl 238): 103-111

13. Cavallo T, Pinto JA, Rajaraman S (1984) Immune complex disease complicating diabetic glomerulosclerosis. Am J Nephrol 4: 347-354 
14. Bloodworth JMB, Engerman RL (1971) Spontaneous and induced diabetic microangiopathy. Acta Diabetol Lat (Suppl 1) 8: 263-298

15. Jones CW, West MS, Hong DT, Jonasson O (1984) Peripheral glomerular basement membrane thickness in the normal and diabetic monkey. Lab Invest 51: 193-198

16. Osterby R (1971) Quantitative electron microscopy of the glomerular basement membrane. A methodologic study. Lab Invest 25: $15-24$

17. Snedecor GW, Cochran WG (1967) Statistical methods. Iowa State University Press, Ames, Iowa, pp 275-298

18. Bojanovski D, Alaupovic P, Kelley JL, Stout C (1978) Isolation and characterization of the major lipoprotein density classes of normal and diabetic baboon (Papio Anubis) plasma. Atherosclerosis 31: $481-487$

19. Steffes MW, Barbosa J, Basgen JM, Sutherland DER, Najarian JS, Mauer SM (1983) Quantitative glomerular morphology of the normal human kidney. Lab Invest 49: 82-86

20. Rasch R (1979) Prevention of diabetic glomerulopathy in streptozotocin diabetic rats by insulin treatment: glomerular basement membrane thickness. Diabetologia 16: 319-324

21. Steffes MW, Brown DM, Basgen JM, Matas AJ, Mauer SM (1979) Glomerular basement membrane thickness following islet transplantation in the rat. Lab Invest 41: 116-118

22. Steffes MW, Mauer SM (1984) Diabetic glomerulopathy in man and experimental animal models. In: Richter GW, Epstein MA (eds) International review of experimental pathology, vol 26. Academic Press, Orlando San Diego San Francisco, pp 147-175

23. Hirose K, Osterby R, Nozawa M, Gunderson HJG (1982) Development of glomerular lesions in experimental long-term diabetes in the rat. Kidney Int 21: 689-695
24. Steffes MW, Buchwald H, Wigness BD, Grappoli TJ, Rupp WM, Rohde TD, Blackshear PJ, Mauer SM (1982) Diabetic nephropathy in the uninephrectomized dog: microscopic lesions after one year. Kidney Int 21:721-724

25. Gibbs GE, Wilson RB, Gifford $H$ (1966) Glomerulosclerosis in the long term alloxan diabetic monkey. Diabetes 15: 258-261

26. Yasuda H, Harano Y, Kosugi T, Nakano M, Suzuki Y, Tsuruoka Y, Taniguchi T, Nishimori R, Kikkawa R, Shigeta Y (1984) Development of early lesions of microangiopathy in chronically diabetic monkeys. Diabetes 33: 415-420

27. Rasch R (1979) Prevention of diabetic glomerulopathy in streptozotocin diabetic rats by insulin treatment. The mesangial regions. Diabetologia 17: 243-248

28. Steffes MW, Brown DW, Basgen JM, Mauer SM (1980) Amelioration of mesangial volume and surface alternations following islet transplantation in diabetic rats. Diabetes 29:509 -515

29. Alperin JB, Dow PA, Stout LC (1979) A comparison of hemoglobin A1c in human and baboon blood. Acta Haematol 61: 334-338

Received: 2 April 1986

and in revised form: 22 July 1986

Dr. L. Clarke Stout

Division of Surgical Pathology

Department of Pathology

The University of Texas Medical Branch

Galveston, TX 77550

USA 